\title{
Recurrent Spontaneous Miscarriage: \\ a Comparison of International Guidelines
}

\author{
Rezidivierende Spontanaborte: \\ ein Vergleich internationaler Leitlinien
}

\section{(ㄷ) (i) $($ 오 $\Theta$}

\author{
Authors \\ Johannes Zschocke ${ }^{3}$, Bettina Toth ${ }^{1}$

\section{Affiliations} \\ 1 Medical University Innsbruck, Department of Gynaeco- \\ logical Endocrinology and Reproductive Medicine, \\ Innsbruck, Austria \\ 2 Zentrum für Gynäkologie und Geburtshilfe, St Elisabethen- \\ Krankenhaus Lörrach gGmbH, Lörrach, Germany \\ 3 Zentrum für medizinische Genetik, Medizinische \\ Universität Innsbruck, Innsbruck, Austria
}

Kilian Vomstein $^{1 *}$, Anna Aulitzky ${ }^{1}$, Laura Strobel ${ }^{1}$, Michael Bohlmann ${ }^{2}$, Katharina Feil ${ }^{1}$, Sabine Rudnik-Schöneborn ${ }^{3}$,

\author{
$\Theta$ \\ Deutsche Version unter: \\ https://doi.org/10.1055/a-1380-3657
}

\section{ABSTRACT}

Key words

miscarriage, genetics, infertility

Schlüsselwörter

Abort, Genetik, Infertilität

received

8. 12.2020

accepted after revision

1.2. 2021

published online

23.4.2021

Bibliography

Geburtsh Frauenheilk 2021; 81: 769-779

DOI 10.1055/a-1380-3657

ISSN 0016-5751

(c) 2021. The Author(s).

This is an open access article published by Thieme under the terms of the Creative Commons Attribution-NonDerivative-NonCommercial-License, permitting copying and reproduction so long as the original work is given appropriate credit. Contents may not be used for commercial purposes, or adapted, remixed, transformed or built upon. (https://creativecommons.org/licenses/by-nc-nd/4.0/)

Georg Thieme Verlag KG, Rüdigerstraße 14,

70469 Stuttgart, Germany

\section{Correspondence}

Dr. Katharina Feil

Medical University Innsbruck, Department of Gynaecological

Endocrinology and Reproductive Medicine

Anichstraße 35, 6020 Innsbruck, Austria

katharina.feil@i-med.ac.at

* contributed equally
While roughly $30 \%$ of all women experience a spontaneous miscarriage in their lifetime, the incidence of recurrent (habitual) spontaneous miscarriage is $1-3 \%$ depending on the employed definition. The established risk factors include endocrine, anatomical, infection-related, genetic, haemostasis-related and immunological factors. Diagnosis is made more difficult by the sometimes diverging recommendations of the respective international specialist societies. The present study is therefore intended to provide a comparison of existing international guidelines and recommendations. The guidelines of the ESHRE, ASRM, the DGGG/OEGGG/SGGG and the recommendations of the RCOG were analysed. It was shown that investigation is indicated after 2 clinical pregnancies and the diagnosis should be made using a standardised timetable that includes the most frequent causes of spontaneous miscarriage. The guidelines concur that anatomical malformations, antiphospholipid syndrome and thyroid dysfunction should be excluded. Moreover, the guidelines recommend carrying out pre-conception chromosomal analysis of both partners (or of the aborted material). Other risk factors have not been included in the recommendations by all specialist societies, on the one hand because of a lack of diagnostic criteria (luteal phase insufficiency) and on the other hand because of the different age of the guidelines (chronic endometritis). In addition, various economic and consensus aspects in producing the guidelines influence the individual recommendations. An understanding of the underlying decision-making process should lead in practice to the best individual diagnosis and resulting treatment being offered to each couple.

\section{ZUSAMMENFASSUNG}

Während etwa 30\% aller Frauen in ihrem Leben einen Spontanabort erleben, beträgt die Inzidenz für rezidivierende (habituelle) Spontanaborte 1-3\% abhängig von der angewandten Definition. Zu den etablierten Risikofaktoren zählen endo- 
krine, anatomische, infektiologische, genetische, hämostaseologische und immunologische Faktoren. Die Diagnostik ist jedoch durch teilweise divergierende Empfehlungen der jeweiligen internationalen Fachgesellschaften erschwert. Der vorliegende Artikel soll daher einen Vergleich der bestehenden internationalen Leitlinienempfehlungen geben. Hierzu werden die Leitlinien der ESHRE, ASRM, der DGGG/OEGGG/ SGGG sowie die Empfehlungen des RCOG analysiert. Es zeigt sich, dass eine Abklärung bereits nach 2 klinischen Schwangerschaften indiziert ist und die Diagnostik anhand eines standardisierten Fahrplans erfolgen sollte, der die häufigsten Ursachen für wiederholte Spontanaborte umfasst. Die Leitlinien sind sich einig, dass der Ausschluss anatomischer Malformationen, eines Antiphospholipidsyndroms sowie von Schilddrüsendysfunktionen erfolgen sollte. Darüber hinaus empfeh- len die Leitlinien die Durchführung einer Chromosomenanalyse beider Partner präkonzeptionell (oder aus dem Abortmaterial). Andere Risikofaktoren sind zum einen aufgrund fehlender diagnostischer Kriterien (Lutealphaseninsuffizienz), zum anderen aufgrund des unterschiedlichen Alters der Leitlinien (chronische Endometritis) nicht von allen Fachgesellschaften in die Empfehlungen aufgenommen. Zusätzlich haben unterschiedliche gesundheitsökonomische und Konsensusaspekte im Rahmen der Leitlinienerstellung Einfluss auf die einzelnen Empfehlungen. Das Verständnis der zugrunde liegenden Entscheidungsprozesse sollte in der Praxis dazu führen, dass für das jeweilige Paar die individuell beste Diagnostik und die sich daraus ableitende Therapie angeboten wird.

\section{Introduction}

Pregnancy loss from conception up to the 24th week of pregnancy or up to a foetal weight of $500 \mathrm{~g} \mathrm{[1]} \mathrm{is} \mathrm{defined} \mathrm{by} \mathrm{the} \mathrm{WHO}$ as abortion or miscarriage. Recurrent spontaneous miscarriage (RM) is defined by the WHO as the occurrence of 3 or more consecutive miscarriages before the 20th week of pregnancy. The American Society for Reproductive Medicine (ASRM), by contrast, defines RM as occurring after just two miscarriages with clinical evidence of pregnancy (sonographic or histopathological) [2 -4].

Roughly $1-3 \%$ of couples who want to have children are affected by RM, sometimes with major consequences for their relationship and quality of life [5]. The established risk factors include endocrine, anatomical, infection-related, genetic, haemostasisrelated and immunological factors. A cause can be found in only about $50 \%$ of women following standardised diagnostics, while it remains unclear in the other $50 \%$, so there is an urgent need to establish new approaches for diagnosis and treatment. In the last few years, guidelines and recommendations dealing with the diagnosis and treatment of RM have been produced by various specialist societies. However, there are sometimes substantial differences in the approaches to diagnosis and treatment, not least in the definition of RM ( $\triangleright$ Table 1 ). For this reason, the current inter- national guidelines of the European Society of Reproduction and Embryology (ESHRE) [6], the American Society of Reproductive Medicine (ASRM) [2,3] and the German, Austrian and Swiss Societies for Gynaecology and Obstetrics (DGGG/OEGGG/SGGG) [7], and the recommendations of the Royal College of Obstetricians and Gynaecologists (RCOG) [8] are compared in this article. The aim is to give an overview of the current status of the diagnosis and treatment of RM and to provide treating physicians with recommendations on management that may go beyond the current recommendations in their respective countries.

\section{Methods}

The guidelines of the ESHRE, ASRM, the DGGG/OEGGG/SGGG and the recommendations of the RCOG were compared with regard to current recommendations on diagnosis and treatment. The areas of genetics, anatomy, infectious disease, endocrinology, coagulation and immunology were analysed in particular ( $\vee$ Tables 2 and 3 ). The cited guidelines were published in the period 2011 to 2018. The 2011 recommendations of the RCOG were updated in 2014 and 2017, and the expert opinion of the ASRM was updated in 2012. The DGGG/OEGGG/SGGG guideline is updated every 3 years in a consensus process.

- Table 1 Definition of RM in the guidelines.

\begin{tabular}{|c|c|c|c|}
\hline ESHRE & DGGG/OEGGG/SGGG & ASRM & RCOG \\
\hline$\geq 2$ miscarriages & $\geq 3$ consecutive miscarriages & $\begin{array}{l}\geq 2 \text { miscarriages (after sonographic or histo- } \\
\text { pathological confirmation of pregnancy) }\end{array}$ & $\geq 3$ consecutive miscarriages \\
\hline \multicolumn{4}{|c|}{ Procedure recommended by the authors of this article } \\
\hline \multicolumn{4}{|c|}{$\begin{array}{l}\text { In women }<35 \text { years possibly after } \geq 2 \text { miscarriages, adjusted to other factors, such as sonographic or histopathological confirmation of pregnancy, } \\
\text { autoimmune diseases, anatomical anomalies or other existing risk factors. In women }>35 \text { years after } \geq 3 \text { consecutive miscarriages. }\end{array}$} \\
\hline
\end{tabular}


- Table 2 Diagnosis of RM. Relevant differences between the guideline recommendations are shown in bold. The measures recommended by the authors' team are shown in italics.

\begin{tabular}{|c|c|c|c|c|}
\hline & ESHRE & DGGG/OEGGG/SGGG & ASRM & RCOG \\
\hline \multicolumn{5}{|l|}{ Genetics } \\
\hline $\begin{array}{l}\text { - Chromosome } \\
\text { analysis } \\
\text { of parents }\end{array}$ & $\begin{array}{l}\text { Chromosome analysis only } \\
\text { with increased genetic risk }\end{array}$ & $\begin{array}{l}\text { Microscopic chromosome analysis } \\
\text { of both partners }\end{array}$ & $\begin{array}{l}\text { Microscopic chromosome } \\
\text { analysis of both partners }\end{array}$ & $\begin{array}{l}\text { Microscopic chromosome } \\
\text { analysis of both partners } \\
\text { only with evidence of a } \\
\text { structural chromosomal } \\
\text { disorder in the aborted } \\
\text { material }\end{array}$ \\
\hline $\begin{array}{l}\text { - Chromosome } \\
\text { analysis } \\
\text { of embryo }\end{array}$ & $\begin{array}{l}\text { Chromosome analysis } \\
\text { of aborted material } \\
\text { not recommended }\end{array}$ & $\begin{array}{l}\text { Chromosome analysis of aborted } \\
\text { material optional }\end{array}$ & - & $\begin{array}{l}\text { Chromosome analysis } \\
\text { of aborted material } \\
\text { recommended from the } \\
\text { 3rd miscarriage }\end{array}$ \\
\hline Coagulation & $\begin{array}{l}\text { No screening for hereditary } \\
\text { thrombophilia (except with } \\
\text { other risk factors and for } \\
\text { research purposes) }\end{array}$ & $\begin{array}{l}\text { Only women with risks for } \\
\text { thromboembolic events: } \\
\text { Determination of factor V Leiden } \\
\text { and prothrombin mutations and } \\
\text { of antithrombin, protein C and } \\
\text { protein S activity }\end{array}$ & $\begin{array}{l}\text { Only in women with a } \\
\text { positive personal or family } \\
\text { history of thromboembolic } \\
\text { events }\end{array}$ & $\begin{array}{l}\text { No explicit recommendation } \\
\text { for women with RM }\end{array}$ \\
\hline \multicolumn{5}{|l|}{ Immunology } \\
\hline - APLS & $\begin{array}{l}\text { ACA (IgM, IgG), } \beta 2 \text {-glyco- } \\
\text { protein I antibodies; LAC }\end{array}$ & $\begin{array}{l}\text { ACA (IgM, IgG), } \beta 2 \text {-glycoprotein I } \\
\text { antibodies; LAC } \\
\text { Non-criteria APLS with clinical } \\
\text { manifestations }\end{array}$ & $\begin{array}{l}\text { ACA (IgM, IgG), } \beta 2 \text {-glyco- } \\
\text { protein I antibodies; LAC }\end{array}$ & ACA $(\operatorname{IgM}, \lg G) L A C$ \\
\hline - ANA & $\begin{array}{l}\text { ANA for explanation } \\
\text { of possible cause }\end{array}$ & $\begin{array}{l}\text { If elevated ANA titres are diagnosed } \\
\text { in RM patients, the antibodies should be } \\
\text { further differentiated (SS-A/RO and } \\
\text { SS-B/lupus anticoagulant [LAC] anti- } \\
\text { bodies) to exclude Sjogren syndrome } \\
\text { or lupus erythematosus. }\end{array}$ & & \\
\hline - other & $\begin{array}{l}\text { HLA-DRB1*05:01/05:02 } \\
\text { in Scandinavian women } \\
\text { with secondary RM }\end{array}$ & $\begin{array}{l}\text { IgA antibodies against transglutami- } \\
\text { nase } \\
\text { Other immunological tests only with } \\
\text { pre-existing autoimmune disease }\end{array}$ & & \\
\hline Anatomy & $\begin{array}{l}\text { 3-D sonography } \\
\text { possibly SHG } \\
\text { possibly HSG } \\
\text { possibly MRI }\end{array}$ & $\begin{array}{l}\text { Sonography } \\
\text { HSC }\end{array}$ & $\begin{array}{l}\text { SHG } \\
\text { HSG } \\
\text { possibly HSC } \\
\text { possibly MRI } \\
\text { possibly 3-D sonography }\end{array}$ & $\begin{array}{l}\text { Sonography } \\
\text { HSG } \\
\text { possibly HSC + LSC } \\
\text { possibly 3-D sonography }\end{array}$ \\
\hline \multicolumn{5}{|l|}{ Endocrinology } \\
\hline - Thyroid & $\begin{array}{l}\text { Thyroid tests and monitoring } \\
\text { of TSH }\end{array}$ & Thyroid tests and monitoring of TSH & $\begin{array}{l}\text { Thyroid tests and monitoring } \\
\text { of TSH }\end{array}$ & $\begin{array}{l}\text { Thyroid tests and monitoring } \\
\text { of TSH }\end{array}$ \\
\hline - Prolactin & $\begin{array}{l}\text { Investigation if typical } \\
\text { symptoms }\end{array}$ & - & $\begin{array}{l}\text { Investigation of hyper- } \\
\text { prolactinaemia }\end{array}$ & Data inconsistent \\
\hline - Glucose & $\begin{array}{l}\text { No investigation of glucose } \\
\text { status }\end{array}$ & Investigation of glucose status & $\begin{array}{l}\text { Investigation of glucose } \\
\text { status }\end{array}$ & $\begin{array}{l}\text { No investigation of glucose } \\
\text { status }\end{array}$ \\
\hline - PCOS & $\begin{array}{l}\text { No investigation of PCOS } \\
\text { or hyperandrogenaemia }\end{array}$ & $\begin{array}{l}\text { Investigation of PCOS and } \\
\text { hyperandrogenaemia }\end{array}$ & $\begin{array}{l}\text { Investigation of PCOS and } \\
\text { hyperandrogenaemia } \\
\text { regarded as controversial }\end{array}$ & $\begin{array}{l}\text { No investigation of PCOS } \\
\text { and hyperandrogenaemia }\end{array}$ \\
\hline - Luteal phase & $\begin{array}{l}\text { Luteal phase tests } \\
\text { not recommended }\end{array}$ & Luteal phase tests can be considered & $\begin{array}{l}\text { Luteal phase tests } \\
\text { can be considered }\end{array}$ & $\begin{array}{l}\text { Luteal phase tests } \\
\text { controversial }\end{array}$ \\
\hline
\end{tabular}


Table 2 Diagnosis of RM. Relevant differences between the guideline recommendations are shown in bold. The measures recommended by the authors' team are shown in italics. (Continued)

\begin{tabular}{l|l|l|l|l|}
\hline & ESHRE & DGGG/OEGGG/SGGG & ASRM & RCOG \\
\hline $\begin{array}{l}\text { Infectious } \\
\text { disease }\end{array}$ & - & $\begin{array}{l}\text { No screening by vaginal swabs } \\
\text { in asymptomatic women }\end{array}$ & $\begin{array}{l}\text { Screening by vaginal swabs } \\
\text { not recommended }\end{array}$ & - \\
\hline $\begin{array}{l}\text { Infection } \\
\text { screening }\end{array}$ & $\begin{array}{l}\text { Further studies on the status } \\
\text { of chronic endometritis in } \\
\text { RM necessary. }\end{array}$ & $\begin{array}{l}\text { Endometrial biopsy can be performed } \\
\text { to exclude chronic endometritis } \\
\text { (CD138). }\end{array}$ & \\
\hline $\begin{array}{l}\text { Chronic } \\
\text { endometritis }\end{array}$ & & & \\
\hline
\end{tabular}

ACA = anticardiolipin antibody; ANA = antinuclear antibody; APLS = antiphospholipid syndrome; ASRM = American Society for Reproductive Medicine; CD138 = Cluster of Differentiation 138; DGGG/OEGGG/SGGG = German, Austrian and Swiss Societies for Gynaecology and Obstetrics; ESHRE = European Society of Human Reproduction and Embryology; HLA = human leucocyte antigen; HSG = hysterosalpingography; HSC = hysteroscopy; IgA = immunoglobulin A; IgG = immunoglobulin G; IgM = immunoglobulin M; LAC = lupus anticoagulant; LSC = laparoscopy; MRI = magnetic resonance imaging; PCOS = polycystic ovarian syndrome; RCOG = Royal College of Obstetricians and Gynaecologists; RM = recurrent (habitual) spontaneous miscarriage; SHG = sono-hysterography; SS-A/RO = Sjogren syndrome antigen A antibody; SS-B = Sjogren syndrome antigen B antibody; $T$ SH = thyroid stimulating hormone.

\section{Genetics}

\section{Cytogenetic tests}

A balanced chromosomal rearrangement in one of the partners is found in about $4-5 \%$ of RM couples [9]. The incidence of structural chromosomal disorder per couple increases from $0.7 \%$ in the ordinary population to $2.0 \%$ after 1 miscarriage, $4.4 \%$ after 2 miscarriages and $5.1 \%$ after 3 miscarriages. Moreover, a family history of miscarriages, stillbirths or malformation syndromes and intellectual disability can indicate familial chromosomal disorders, regardless of whether healthy children were born, including between the miscarriages.

The probability of a structural chromosomal disorder decreases with increasing maternal age at the second miscarriage and increases with a family history of miscarriage (2 or more miscarriages in first-degree relatives) [10]. According to the ESHRE guideline chromosomal analysis is not regarded as indicated with RM, though incorrectly calculated numbers are pointed out. An incidence of $1.9 \%$ was originally given for the confirmation of a balanced chromosomal aberration in couples with RM, but this was based on an insufficient consideration of the studies and also on an incorrect calculation in the only study referred to [11]. In this study, 406 balanced chromosomal aberrations were found in 20432 persons, which corresponds to a per-couple rate of about $4 \%$; the error was corrected in the guideline provided online in 2019 (version 2, available at https://www.eshre.eu). It is argued in the ESHRE guideline that the risk of birth of a disabled child because of a parental balanced chromosomal rearrangement is negligible. This probability was originally given in the ESHRE guideline as $0.02 \%$ and corrected to $0.04 \%$ in 2019 but is actually $1 / 1.315$ or approx. $0.08 \%[11,12]$. The authors of the German-language guideline were of the opinion that this is not negligible.

The international specialist societies do not agree on whether couples with RM should be offered chromosomal analysis and, if so, whether this should be done after two or after three miscar- riages. It is recommended in the majority of the guidelines that microscopic chromosomal analysis (karyotyping) should be performed in both partners in the case of RM. A chromosomal disorder can be found in the aborted material by chromosomal analysis but the sensitivity for detection of the prognostically relevant small structural chromosomal rearrangements (especially balanced translocations) is often lower than with chromosomal analysis from whole blood. An alternative is to examine the aborted tissue by DNA array, which also detects smaller aberrations (deletions and duplications). This analysis is often more expensive than classic chromosomal analysis, however. The British ROCG guideline recommends primary (molecular) cytogenetic analysis of aborted material after the 3rd miscarriage.

\section{Preimplantation tests}

Aneuploidy screening (preimplantation genetic screening, PGS, or PGT-A, preimplantation genetic testing for aneuploidies) is often offered as a preimplantation test as part of assisted reproduction treatment; the aim is to achieve greater live birth rates (LBR) by transferring euploid embryos. However, women with a history of miscarriage have a high probability of becoming pregnant again spontaneously.

The LBR per cycle after artificial fertilisation is about $35 \%$ with PGT-A, whereas the probability of a live birth in the next cycle of a spontaneously occurring pregnancy after RM is about $60 \%$ [13].

According to the studies to date, there is no evidence that PGT-A leads to an increased LBR after RM compared with spontaneous pregnancies. This also applies for couples with a genetic predisposition due to a balanced chromosomal aberration in one partner. Couples with a structural chromosomal rearrangement who become pregnant naturally have a markedly higher rate of miscarriage, however, than couples who become pregnant after PGS, which can lead to considerable psychological stress. No specialist society currently recommends preimplantation screening for couples with RM ( $\triangleright$ Table 3 ). 
- Table 3 Treatment of RM. Relevant differences between the guideline recommendations are shown in bold. The measures recommended by the authors' team are shown in italics.

\begin{tabular}{|c|c|c|c|c|}
\hline & ESHRE & DGGG/OEGGG/SGGG & ASRM & RCOG \\
\hline Genetics & $\begin{array}{l}\text { PID/PGT-A not } \\
\text { recommended }\end{array}$ & PID/PGT-A not recommended & $\begin{array}{l}\text { PID/PGT-A not } \\
\text { recommended }\end{array}$ & $\begin{array}{l}\text { PID/PGT-A not } \\
\text { recommended }\end{array}$ \\
\hline Coagulation & $\begin{array}{l}\text { Anticoagulation in hereditary } \\
\text { thrombophilia only for } \\
\text { thrombosis prophylaxis in the } \\
\text { mother (and in studies) }\end{array}$ & $\begin{array}{l}\text { Anticoagulation in hereditary } \\
\text { thrombophilia only for thrombosis } \\
\text { prophylaxis in the mother }\end{array}$ & $\begin{array}{l}\text { No explicit recommendation } \\
\text { on treatment in women with } \\
\text { RM }\end{array}$ & $\begin{array}{l}\text { Inadequate data on anti- } \\
\text { coagulation with heparin for } \\
\text { secondary prophylaxis in } \\
\text { women with RM and throm- } \\
\text { bophilia (no recommen- } \\
\text { dation) }\end{array}$ \\
\hline \multicolumn{5}{|l|}{ Immunology } \\
\hline - APLS & $\begin{array}{l}\text { Low dose aspirin ( } 75- \\
100 \text { mg daily) in combina- } \\
\text { tion with unfractionated/ } \\
\text { low molecular weight } \\
\text { heparin from positive } \\
\text { pregnancy test. }\end{array}$ & $\begin{array}{l}\text { Low dose aspirin ( } 75-100 \text { mg daily) } \\
\text { in combination with unfractionated/ } \\
\text { low molecular weight heparin from } \\
\text { positive pregnancy test. Aspirin until } \\
34+0 \text { weeks of pregnancy, unfrac- } \\
\text { tionated/low molecular weight } \\
\text { heparin until } 6 \text { weeks post partum }\end{array}$ & $\begin{array}{l}\text { Treatment of APLS with low } \\
\text { dose aspirin in combination } \\
\text { with unfractionated heparin }\end{array}$ & $\begin{array}{l}\text { Treatment of APLS with low } \\
\text { dose aspirin in combination } \\
\text { with unfractionated/low } \\
\text { molecular weight heparin }\end{array}$ \\
\hline - other & - & $\begin{array}{l}\text { Immunoglobulins, allogeneic lympho- } \\
\text { cyte therapy, lipid infusions, TNF- } \alpha \\
\text { blockers and glucocorticoids only in } \\
\text { clinical studies }\end{array}$ & $\begin{array}{l}\text { i. v. administration of } \\
\text { immunoglobulins is not } \\
\text { recommended }\end{array}$ & $\begin{array}{l}\text { Warning about the possi- } \\
\text { bility of an increase in ma- } \\
\text { ternal and foetal morbidity } \\
\text { if immunomodulatory treat- } \\
\text { ments are given }\end{array}$ \\
\hline Anatomy & $\begin{array}{l}\text { Insufficient data for septum } \\
\text { resection/myoma or polyp } \\
\text { resection and adhesiolysis }\end{array}$ & $\begin{array}{l}\text { Septum resection } \\
\text { Intrauterine adhesiolysis } \\
\text { Myoma resection (submucous) } \\
\text { Resection of polyps }\end{array}$ & Septum resection & $\begin{array}{l}\text { Insufficient data for septum } \\
\text { resection }\end{array}$ \\
\hline \multicolumn{5}{|l|}{ Endocrinology } \\
\hline - Thyroid & $\mathrm{TSH}<2.5$ & $T S H<2.5$ & $\mathrm{TSH}<2.5$ & TSH $<2.5$ \\
\hline - Prolactin & Bromocriptine & - & Bromocriptine & Data inconsistent \\
\hline - Glucose & $\begin{array}{l}\text { Optimal control of diabetes } \\
\text { mellitus } \\
\text { No recommendation on } \\
\text { metformin for impaired } \\
\text { glucose tolerance }\end{array}$ & $\begin{array}{l}\text { Optimal control of diabetes mellitus } \\
\text { No recommendation on metformin } \\
\text { for impaired glucose tolerance }\end{array}$ & $\begin{array}{l}\text { Optimal control of diabetes } \\
\text { mellitus } \\
\text { No recommendation on } \\
\text { metformin for impaired } \\
\text { glucose tolerance }\end{array}$ & $\begin{array}{l}\text { Optimal control of diabetes } \\
\text { mellitus } \\
\text { No recommendation on } \\
\text { metformin for impaired } \\
\text { glucose tolerance }\end{array}$ \\
\hline - Luteal phase & No luteal phase support & $\begin{array}{l}\text { Luteal phase support } \\
\text { can be considered }\end{array}$ & $\begin{array}{l}\text { Luteal phase support } \\
\text { can be considered }\end{array}$ & $\begin{array}{l}\text { Luteal phase support } \\
\text { regarded as controversial }\end{array}$ \\
\hline \multicolumn{5}{|l|}{$\begin{array}{l}\text { Infectious } \\
\text { disease }\end{array}$} \\
\hline $\begin{array}{l}\text { - Chronic } \\
\text { endometritis }\end{array}$ & $\begin{array}{l}\text { Further studies on the status } \\
\text { of chronic endometritis in } \\
\text { RM necessary. }\end{array}$ & $\begin{array}{l}\text { If chronic endometritis is confirmed } \\
\text { antibiotic therapy can be given. }\end{array}$ & - & - \\
\hline
\end{tabular}

\section{Anatomy}

\section{Diagnosis}

Women with RM appear to have a higher incidence of uterine anomalies, with a reported rate between 3 and $25 \%[14,15]$. Whether the presence of uterine anomalies leads to RM is unknown [16]. The increased probability of miscarriage with subsep- tate uterus is recognised. How far RM is associated with other congenital or acquired uterine anomalies such as polyps, myomas or adhesions is unclear.

The guideline of the DGGG/OEGGG/SGGG recommends hysteroscopy (HSC) to diagnose a uterine anomaly, possibly in combination with laparoscopy (LSC), or 3-D sonography or MRI [7]. The ESHRE guideline likewise advises exclusion of uterine anomalies and recommends that this be done by 3-D sonography [6]. The 
RCOG also supports sonographic investigation and recommends further diagnosis of anomalies by means of 3-D sonography or HSC in combination with LSC [8]. The ASRM also recommends exclusion of uterine anomalies and the diagnostic methods of choice are hysterosonography, hysterosalpingography, MRI, 3-D sonography or HSC.

\section{Treatment}

A meta-analysis from 2017 showed that no randomised studies on the therapeutic effect of septum dissection had been conducted to date [17]. Hysteroscopic septum dissection is generally recommended or can be recommended for women with RM and a uterine septum [18]. A recent retrospective multicentre study, however, did not show any benefit of septum dissection with regard to LBR or the rate of miscarriage [19]. Operative intervention is not indicated for other congenital uterine anomalies such as bicornuate uterus, uterus didelphys und arcuate uterus [20].

Other conditions such as removal of adhesions, myomas or polyps are listed mainly in the DGGG/OEGGG/SGGG guideline (exception: myomas are also mentioned in the ASRM). The treatment of choice of intrauterine adhesions is hysteroscopic adhesiolysis $[21,22]$. Whether intrauterine adhesions influence the risk of miscarriage in general or only above a certain degree or whether adhesiolysis reduces this risk is unclear, however. Nevertheless, the German-language guideline recommends resection of uterine adhesions.

There is evidence, however, that myoma enucleation leads to an improved pregnancy rate, especially in the case of myomas impinging on the uterine cavity. Consideration of myoma resection depending on its position is therefore recommended in both the DGGG/OEGGG/SGGG and the ASRM guidelines [21].

A meta-analysis and a systematic review showed that hysteroscopic resection of intrauterine polyps visible on ultrasound prior to intrauterine insemination can increase the clinical pregnancy rate but a clear benefit with regard to the rate of miscarriage was not shown $[23,24]$. If there is no other explanation for the cause, resection of persisting polyps can be considered for RM patients according to the DGGG/OEGGG/SGGG guideline.

\section{Infectious Disease}

\section{Diagnosis}

Bacterial vaginosis

The influence of bacterial, viral or parasitic vaginal infections on RM remains controversial so no guideline includes general screening in asymptomatic patients to prevent miscarriage. Because of the association between vaginal dysbiosis and pregnancy complications (cervical insufficiency, premature rupture of the membranes with amniotic infection syndrome), the German-language guideline recommends investigation in a suspected case and appropriate treatment as part of antenatal care $[25,26]$.

\section{Chronic endometritis}

Chronic endometritis (CE), which has a prevalence of $7-67 \%$ in women with RM, is presented as a risk factor in some studies [28, 74 - 76]. Endometrial biopsy with subsequent immunohistochem- ical examination is necessary for diagnosis of CE. This detects plasma cells with an antibody against syndecan-1 (CD138), which has largely replaced conventional haematoxylin-eosin staining [75]. The recommendation to exclude CE is currently found only in the German-language guideline, while the ESHRE interprets the studies as not yet sufficient. The guidelines of the ASRM and RCOG do not contain any reference to CE but these guidelines are older.

\section{Treatment}

Bacterial vaginosis

Only the German-language guideline mentions a study in which treatment of confirmed bacterial vaginosis between the 12th and 22nd week of pregnancy by giving clindamycin (300 mg orally twice daily for 5 days) significantly reduced the incidence of miscarriage in the 2 nd trimester and the rate of premature birth [27]. However, this study does not result in an explicit recommendation.

\section{Chronic endometritis}

The DGGG/OEGGG/SGGG recommends antibiotic therapy, e.g., with doxycycline (200 mg daily for 14 days) if CE is confirmed. After the treatment, an increase of $19 \%$ in the LBR was described, and patients with repeated implantation failure also benefited from this in further IVF treatment $[28,29]$. Nevertheless, the ESHRE guideline refrains from making a treatment recommendation.

\section{Endocrinology}

\section{Diagnosis}

Impaired glucose tolerance and PCOS

Endocrine factors can play an important part in RM. Disorders of glucose tolerance, especially poorly controlled diabetes mellitus, can be regarded as risk factors for RM $[30,31]$. All the parameters of the metabolic syndrome including obesity and associated hyperandrogenaemia as well as polycystic ovarian syndrome (PCOS) $[32,33]$ are noted by the guidelines as positive risk factors. The ESHRE guideline does not recommend exclusion of PCOS or measurement of glucose status as the authors, while they see this as associated with RM, do not find clear evidence from current data that treatment leads to an improved LBR [34]. Investigation of hyperandrogenaemia is also not recommended by the ESHRE. The authors of the ARM guideline recommend investigation of diabetes mellitus or impaired glucose tolerance, whereas exclusion of PCOS and/or hyperandrogenaemia is not among the diagnostic recommendations.

\section{Thyroid dysfunction}

Thyroid dysfunction, predominantly hypothyroidism, should be investigated, according to all guidelines. Measurement of both thyroid-stimulating hormone (TSH) and thyroid antibodies (TPOAb in hypothyroidism and TRAb in hyperthyroidism) and the concentration of free T3/T4 is recommended. 


\section{Hyperprolactinaemia}

Hyperprolactinaemia as a risk factor is mentioned in the ESHRE guideline and the guideline of the ARM. Both refer to two studies, though these showed inconsistent results $[35,36]$. Investigation is therefore recommended only if typical symptoms are present.

Luteal phase insufficiency

With regard to luteal phase insufficiency, different recommendations are found in the international guidelines. This is due not least to the lack of an international definition. The authors of the German-language guideline cite a luteal phase length of less than 12 days and low luteal progesterone levels (without stating a threshold) as diagnostic parameters but at the same time they state that these parameters were never clearly associated with RM. In the expert opinion of the ASRM, likewise, a shortened luteal phase is mentioned as a possible cause of RM but more specific recommendations regarding the diagnosis of this and regarding the minimal duration of the luteal phase are not made. Like the authors of the German-language guideline, they assess the diagnosis and interpretation of the findings as problematic due to the small amount of data. The green-top guideline of the RCOG does not give details of the diagnosis of luteal phase insufficiency. The authors of the ESHRE guideline cite a progesterone level of $<10 \mathrm{ng} / \mathrm{ml}$ or the sum of three serum progesterone levels below $30 \mathrm{ng} / \mathrm{ml}$ as threshold. On the other hand, the temperature curve, length of the luteal phase ( $<11$ days) and diameter of the preovulatory follicle show low sensitivity and specificity [37].

\section{Treatment}

Impaired glucose tolerance and PCOS

A potential positive effect of taking metformin to reduce the rate of miscarriage has not been shown to date from the current data [38]. Therefore, none of the guidelines recommends use of metformin for RM. However, weight reduction in obese patients has a positive effect in connection with RM: a cohort study from Denmark showed that the rate of miscarriage increases above a BMI $\geq 30 \mathrm{~kg} / \mathrm{m}^{2}$ [39]. From this is derived the recommendation of the authors of the S2K guideline of the DGGG/OEGGG/SGGG regarding weight reduction in women with RM and increased BMI. The ESHRE also recommends lifestyle advice, which should include the effects of diet, smoking and alcohol consumption.

\section{Thyroid dysfunction}

In the case of hypothyroidism, achieving a TSH level below $2.5 \mathrm{mU} / \mathrm{ml}$ is recommended uniformly [40]. The TSH levels should also be monitored. The authors of the German-language guideline recommend adjusting the thyroxine dosage in pregnancy by $50 \%$ of the preconception dosage, especially if thyroid autoantibodies are elevated.

The ESHRE mentions thyroid dysfunction and the presence of thyroid autoantibodies as a cause of disorders of folliculogenesis, spermatogenesis, fertilisation and embryogenesis and thus as a cause of subfertility and RM [41]. The authors likewise specify a target TSH of $\leq 2.5 \mathrm{mU} / \mathrm{ml}$ and recommend thyroid hormone replacement $[42,43]$.

\section{Hyperprolactinaemia}

Treatment of hyperprolactinaemia with bromocriptine is recommended by the ESHRE and by the ASRM.

\section{Luteal phase insufficiency}

The currently inconsistent data regarding the definition of luteal phase insufficiency do not permit any conclusion regarding treatment recommendations $[37,44,45]$. In the German-language guideline, however, consideration of luteal phase insufficiency in the treatment of RM is recommended [46]. The authors of the ASRM recommendations come to a similar conclusion since progesterone replacement in the luteal phase can achieve a benefit in selected cases. The authors of the guidelines of the RCOG and ESHRE recommend neither investigation nor treatment of luteal phase insufficiency.

\section{Coagulation}

\section{Diagnosis}

Congenital thrombophilic coagulation disorders are established predisposing factors for thromboembolic events and have also been suggested as risk factors for RM. Up to $15 \%$ of the Caucasian population has a corresponding coagulation disorder [47]. In fact, patients with a history of habitual miscarriage and confirmed factor V Leiden (FVL) or prothrombin mutation have an increased risk of miscarriage in a subsequent pregnancy compared with nonthrombophilic RM patients [48]. A deficiency of the antithrombogenic proteins $S$ and $C$ and of antithrombin is regarded as a miscarriage risk. While there is a physiological decrease in the concentrations of protein $C$ and $S$ in pregnancy so that evaluation is limited during pregnancy and for at least 6 weeks afterwards, genetic tests for factor $\mathrm{V}$ Leiden or prothrombin mutation are independent of this. No indication is seen for measurement of D-dimers [7]. In review articles, "thrombophilia screening" is not regarded as indicated when there is a history of pregnancy complications [49]. The question of the therapeutic consequence of an abnormal finding is more complex, however.

The current ESHRE guideline does not recommend any screening for hereditary thrombophilia in a woman with RM who is seeking advice, except in the context of scientific studies and if there are further risk factors for thromboembolism. The ASRM recommendations support nuanced investigation of thrombophilia with RM when there is a positive personal or family history of thromboembolic events, while the RCOG guideline does not express an opinion explicitly. The German-language recommendation is most specific; it supports further investigation only for women with risks for thromboembolic events, advising investigation for factor $\mathrm{V}$ Leiden or prothrombin mutations and measurement of the activity of antithrombin and proteins $C$ and $S$. The DGGG/ OEGGG/SGGG guideline does not consider thrombophilia investigation as indicated for miscarriage prophylaxis and hence as an embryo-related indication. 


\section{Treatment}

Despite the varied effects of heparins at the molecular level [50] there are currently no high-level prospective randomised studies that show a clear benefit of anticoagulation with a low-molecular-weight heparin to prevent miscarriage in women with RM with or without confirmed hereditary thrombophilia [51-56].

An individualised approach appears necessary from the maternal indication when there is a markedly increased risk of venous thromboembolism (VTE) in thrombophilic pregnant women due to coagulation disorders.

Both the ESHRE and the DGGG/OEGGG/SGGG guidelines advise anticoagulation in pregnancy only in the case of a maternal indication: in the case of hereditary thrombophilia, the mother should be treated only for thrombosis prophylaxis (and in studies). The ASRM and RCOG guidelines make no explicit recommendations, though the British guidelines makes a cross-reference to the recommendations on thrombosis prophylaxis.

\section{Immunology}

\section{Diagnosis}

Various mechanisms are necessary to prevent rejection of the foetus by the mother's immune system. Studies to date of immunological aspects of RM concentrate on antiphospholipid syndrome (APLS), autoantibodies, cytokines, HLA polymorphisms and HLA expression on trophoblasts as well as natural killer cells in peripheral blood and in the endometrium.

\section{Antiphospholipid syndrome}

APLS is regarded as an established risk factor for RM; it occurs in $5-20 \%$ of RM patients and already includes the definition of recurrent spontaneous miscarriage in its diagnostic criteria ( $\bullet$ Table 4 ) [57]. The diagnostic criteria include clinical criteria, on the one hand, such as arterial or venous thrombosis and pregnancy complications ( $\geq 1$ miscarriage after the 10th week of pregnancy or $\geq 3$ miscarriages after the 10th week of pregnancy), and, on the other hand, serological criteria such as demonstration at least twice of antiphospholipid antibodies (ACA: anti-cardiolipin Ab, anti- $\beta 2$-glycoproteins, LAC: lupus anticoagulant) [58]. The antiphospholipid antibody titre should be checked again 12 weeks after the first measurement and should then be again in the middle to high range (>99th percentile measured in normal subjects) [59]. It is suggested that the pathophysiology involves an increased tendency to thrombosis as well as a direct influence on the trophoblast [60]. Secretion of pro-inflammatory cytokines such as TNF, IL-1 and IL-6 is also increased in APLS, leading to increased activation of the immune system [61]. All guidelines recommend testing for $\mathrm{lgG} / \mathrm{IgM} \mathrm{ACA}, \mathrm{LAC}$ and $\beta 2$-glycoprotein I antibodies, though the RCOG guideline does not specifically mention the $\beta 2$-glycoprotein I antibodies. If clinical manifestations are present (livedo reticularis, ulcerations, renal microangiopathy, neurological and cardiac disorders), "non-criteria APLS" should be investigated according to the DGGG/OEGGG/SGGG.
- Table 4 APLS diagnostic criteria (modified from [59]). APLS can be diagnosed when at least one clinical and one laboratory criterion is met.

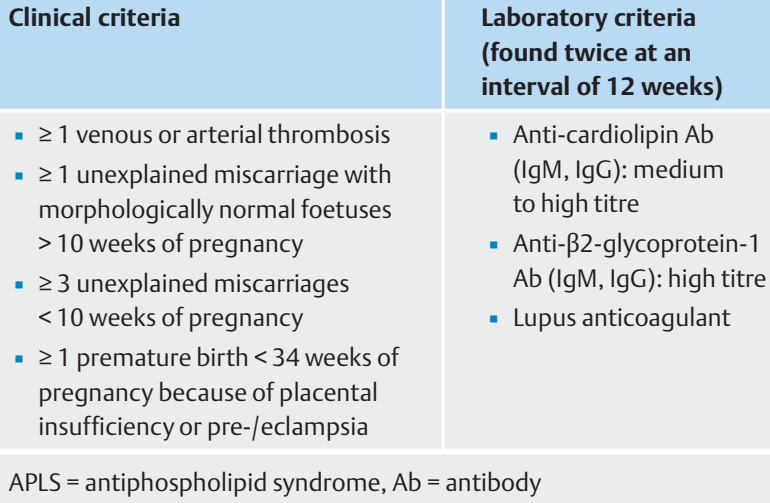

- $\geq 1$ venous or arterial thrombosis

- $\geq 1$ unexplained miscarriage with

- Anti-cardiolipin Ab (IgM, IgG): medium to high titre

morphologically normal foetuses

$>10$ weeks of pregnancy

- $\geq 3$ unexplained miscarriages

$<10$ weeks of pregnancy

- Anti-ß2-glycoprotein-1 $\mathrm{Ab}(\mathrm{IgM}, \lg \mathrm{G})$ : high titre

- Lupus anticoagulant

- $\geq 1$ premature birth < 34 weeks of pregnancy because of placental insufficiency or pre-/eclampsia

APLS = antiphospholipid syndrome, $A b=$ antibody

\section{Other immunomodulatory abnormalities}

If there are food sensitivities, measurement of IgA transglutaminase antibodies to exclude coeliac disease can be considered, according to the German-language guideline. It has been shown that approximately $6 \%$ of women with coeliac disease suffer from RM and RM patients with coeliac disease can benefit from a gluten-free diet [62-64]. Other specialist societies do not recommend testing for coeliac disease.

Antinuclear antibodies (ANA) are an indication of autologous activation of the immune system. A review article from the year 1996 showed an increased prevalence of ANA in 10 of 12 case control studies in patients with RM compared with healthy controls [65]. However, these changes were not significant in all studies. Nevertheless, only the ESHRE guideline currently contains a recommendation to test for ANA in the case of RM, even if only to explain the possible cause. Since higher ANA titres can be linked with autoimmune diseases such as lupus erythematosus and Sjogren syndrome $[66,67]$, the DGGG/SGGG/OEGGG recommends intensified diagnostic tests to exclude these diseases if elevated ANA are found. The antibodies should be further differentiated (SS-A/RO and SS-B/LAC antibodies) so as to diagnose neonatal lupus syndrome or foetal AV block promptly.

The DGGG/OEGGG/SGGG guideline recommends preconception interdisciplinary care in the case of pre-existing autoimmune disorder but without specifying this more precisely.

Furthermore, according to the ESHRE, possible testing for HLADRB1 can be performed in Scandinavian women with secondary spontaneous miscarriage. A distinction between primary and secondary RM with regard to immunological risk factors with reference to possible testing for HLA-DRB1 is discussed only in the guideline of the ESHRE but appears reasonable in light of recent studies $[68,69]$.

\section{Treatment}

\section{Antiphospholipid syndrome}

All guidelines advise treating APLS by giving low-dose aspirin (75$100 \mathrm{mg}$ daily) in combination with unfractionated/low-molecularweight heparin, which is also supported by a recent Cochrane 
analysis [70]. Only the DGGG/OEGGG/SGGG and the ESHRE specify the regimen: the treatment should be started at the same time as the positive pregnancy test. The DGGG/OEGGG/SGGG in addition specifies that aspirin is stopped at $34+0$ weeks of pregnancy and heparin is stopped six weeks post partum. This also applies for “non-criteria” APLS.

\section{Other immunomodulatory treatments}

The German-language guideline recommends giving immunoglobulins, allogeneic lymphocyte transfusion, lipid infusions, TNF- $\alpha$ blockers and glucocorticoids only in the context of clinical studies. By contrast, the RCOG points to the possibility of increasing maternal and foetal morbidity if immunomodulatory treatments are given. The cause of the different recommendations may be the different publication times of the guidelines (between 2011 and 2018).

\section{Conclusion}

Diagnosis in couples with RM presents a particular challenge to treating physicians. In addition to the gynaecological aspects, noting the different course of the miscarriages, a detailed history should also include an in-depth family history. A clearly structured and standardised diagnostic approach is advisable so as to explain the scope of further diagnostic tests to the couples and also to initiate targeted treatment subsequently. However, the existence of different guideline recommendations makes decisions regarding the necessary diagnosis and treatment more difficult. This starts at the time a diagnosis is made as the guidelines use different definitions for RM. When considered more closely, however, diagnostic investigation of the most common causes after just two clinical pregnancies appears justified, as recommended by the ASRM. This was also supported by a recent meta-analysis [71]. In this meta-analysis no difference was found in the prevalence of uterine anomalies (such as subseptate uterus, bicornuate or unicornuate uterus, polyps or adhesions) and APLS in women with two or three miscarriages. Whether the prevalence of chromosomal anomalies, thrombophilia and thyroid disease differs after two or three miscarriages could not be finally clarified from this metaanalysis [71]. A recent Danish registry study showed clearly that both the woman's age and the pregnancy history should be considered in deciding when investigation is recommended. A prediction model for the probability of live birth based solely on these two parameters was insufficient [72]. Therefore, the decision on how many miscarriages should occur before starting to investigate should depend both on the woman's age and number of miscarriages and also on the mother's other diseases [71-73].

Moreover, it is apparent that the guidelines essentially concur regarding evidence-based diagnosis and treatment at the time the guidelines were produced (differences of up to 8 years between the individual guidelines) ( $\vee$ Tables $\mathbf{2}$ and $\mathbf{3}$, differences marked in bold). These include exclusion of anatomical malformations, APLS and thyroid dysfunction. The guidelines also recommend preconception chromosomal analysis of both partners, though the RCOG recommends this only when a structural chromosomal disorder is found in the aborted material.
Risk factors such as luteal phase insufficiency cannot be included in evidence-based guideline recommendations due to the current lack of a definition and the resulting controversial study situation. More recent risk factors such as CE are mentioned only in the German-language and ESHRE guidelines as the RCOG and ASRM recommendations are simply too old to contain more recent developments. Finally, the differences in the recommendations can be attributed to the complex consensus process involved in preparation of the guidelines, which often leads to newer methods of diagnosis and treatment not being included in the recommendations, and this can also have financial causes. Since individual situations require an adapted procedure, it may be necessary to deviate from current guidelines. The approaches to diagnosis and treatment recommended by the authors' team in a normal case are marked in italics in $>$ Tables 2 and $\mathbf{3}$ and largely correspond to the recommendations of the DGGG/OEGGG/SGGG. The diagnostic spectrum should naturally be extended only with consideration of the respective clinical situation.

\section{Conflict of Interest}

Bettina Toth: shareholder of Reprognostics GbR, research funding: Teva, Bayer, Ferring. Fees/reimbursement of costs: Deutsche Gesellschaft für Gynäkologie und Geburtshilfe [German Society of Obstetrics and Gynecology]. Ferring, MSD, Exeltis, Merck Serono, Teva, Bayer. The remaining authors state that they have no conflicts of interest.

\section{References}

[1] [Anonymous]. WHO: recommended definitions, terminology and format for statistical tables related to the perinatal period and use of a new certificate for cause of perinatal deaths. Modifications recommended by FIGO as amended October 14, 1976. Acta Obstet Gynecol Scand 1977; 56: 247-253

[2] Practice Committee of the American Society for Reproductive Medicine. Evaluation and treatment of recurrent pregnancy loss: a committee opinion. Fertil Steril 2012; 98: 1103-1111. doi:10.1016/j.fertnstert. 2012.06.048

[3] Practice Committee of the American Society for Reproductive Medicine. Electronic address aao. Definitions of infertility and recurrent pregnancy loss: a committee opinion. Fertil Steril 2020; 113: 533-535. doi:10.1016/j.fertnstert.2019.11.025

[4] Carrington B, Sacks G, Regan L. Recurrent miscarriage: pathophysiology and outcome. Curr Opin Obstet Gynecol 2005; 17: 591-597. doi:10.1097/01.gco.0000194112.86051.26

[5] Nybo Andersen AM, Wohlfahrt J, Christens P et al. Maternal age and fetal loss: population based register linkage study. BMJ 2000; 320: 17081712. doi:10.1136/bmj.320.7251.1708

[6] ESHRE Guideline Group on RPL, Bender Atik R, Christiansen OB et al. ESHRE guideline: recurrent pregnancy loss. Hum Reprod Open 2018; 2018: hoy004. doi:10.1093/hropen/hoy004

[7] Toth B, Wurfel W, Bohlmann M et al. Recurrent Miscarriage: Diagnostic and Therapeutic Procedures. Guideline of the DGGG, OEGGG and SGGG (S2k-Level, AWMF Registry Number 015/050). Geburtshilfe Frauenheilkd 2018; 78: 364-381. doi:10.1055/a-0586-4568

[8] Royal College of Obstetricians \& Gynaecologists. The investigation and treatment of Couples with recurrent first-trimester and second-trimester miscarriage. RCOG Green-top Guideline 2011; No 17. Accessed September 25, 2020 at: https://www.rcog.org.uk/globalassets/documents/ guidelines/gtg_17.pdf 
[9] De Braekeleer M, Dao TN. Cytogenetic studies in couples experiencing repeated pregnancy losses. Hum Reprod 1990; 5: 519-528

[10] Franssen MT, Korevaar JC, Leschot NJ et al. Selective chromosome analysis in couples with two or more miscarriages: case-control study. BM] 2005; 331: 137-141. doi:10.1136/bmj.38498.669595.8F

[11] Barber JC, Cockwell AE, Grant E et al. Is karyotyping couples experiencing recurrent miscarriage worth the cost? BJOG 2010; 117: 885-888. doi:10.1111/j.1471-0528.2010.02566.x

[12] Franssen MT, Korevaar JC, van der Veen F et al. Reproductive outcome after chromosome analysis in couples with two or more miscarriages: index [corrected]-control study. BM] 2006; 332: 759-763. doi:10.1136/ bmj.38735.459144.2F

[13] Hirshfeld-Cytron J, Sugiura-Ogasawara M, Stephenson MD. Management of recurrent pregnancy loss associated with a parental carrier of a reciprocal translocation: a systematic review. Semin Reprod Med 2011; 29: 470-481. doi:10.1055/s-0031-1293201

[14] Sugiura-Ogasawara M, Ozaki Y, Katano K et al. Uterine Anomaly and Recurrent Pregnancy Loss. Semin Reprod Med 2011; 29: 514-521. doi:10.1055/s-0031-1293205

[15] Salim R, Regan L, Woelfer B et al. A comparative study of the morphology of congenital uterine anomalies in women with and without a history of recurrent first trimester miscarriage. Hum Reprod 2003; 18: 162-166. doi:10.1093/humrep/deg030

[16] Raga F, Casan EM, Bonilla-Musoles F. Expression of vascular endothelial growth factor receptors in the endometrium of septate uterus. Fertil Steril 2009; 92: 1085-1090. doi:10.1016/j.fertnstert.2008.07.1768

[17] Rikken JF, Kowalik CR, Emanuel MH et al. Septum resection for women of reproductive age with a septate uterus. Cochrane Database Syst Rev 2017; (1): CD008576. doi:10.1002/14651858.CD008576.pub4

[18] Valle RF, Ekpo GE. Hysteroscopic metroplasty for the septate uterus: review and meta-analysis. J Minim Invasive Gynecol 2013; 20: 22-42. doi:10.1016/j.jmig.2012.09.010

[19] Rikken JFW, Verhorstert KW], Emanuel MH et al. Septum resection in women with a septate uterus: a cohort study. Human Reprod 2020; 35 : 1578-1588. doi:10.1093/humrep/dez284

[20] Bailey AP, Jaslow CR, Kutteh WH. Minimally Invasive Surgical Options for Congenital and Acquired Uterine Factors Associated with Recurrent Pregnancy Loss. Women's Health 2015; 11: 161-167. doi:10.2217| WHE.14.81

[21] Conforti A, Alviggi C, Mollo A et al. The management of Asherman syndrome: a review of literature. Reprod Biol Endocrinol 2013; 11: 118. doi:10.1186/1477-7827-11-118

[22] Di Guardo F, Della Corte L, Vilos GA et al. Evaluation and treatment of infertile women with Asherman syndrome: an updated review focusing on the role of hysteroscopy. Reprod Biomed Online 2020; 41: 55-61. doi:10.1016/j.rbmo.2020.03.021

[23] Bosteels ], Weyers S. Outpatient treatment for uterine polyps. BM] 2015; 350: h1469. doi:10.1136/bmj.h1469

[24] Zhang H, He X, Tian W et al. Hysteroscopic Resection of Endometrial Polyps and Assisted Reproductive Technology Pregnancy Outcomes Compared with No Treatment: A Systematic Review. J Minim Invasive Gynecol 2019; 26: 618-627. doi:10.1016/j.jmig.2018.10.024

[25] Nigro G, Mazzocco M, Mattia E et al. Role of the infections in recurrent spontaneous abortion. J Matern Fetal Neonatal Med 2011; 24: 983-989. doi:10.3109/14767058.2010.547963

[26] Ng SC, Gilman-Sachs A, Thaker P et al. Expression of intracellular Th1 and Th2 cytokines in women with recurrent spontaneous abortion, implantation failures after IVF/ET or normal pregnancy. Am J Reprod Immunol 2002; 48: 77-86. doi:10.1034/j.1600-0897.2002.01105.x

[27] Ugwumadu A, Manyonda I, Reid F et al. Effect of early oral clindamycin on late miscarriage and preterm delivery in asymptomatic women with abnormal vaginal flora and bacterial vaginosis: a randomised controlled trial. Lancet 2003; 361: 983-988. doi:10.1016/S0140-6736(03)12823-1
[28] McQueen DB, Perfetto CO, Hazard FK et al. Pregnancy outcomes in women with chronic endometritis and recurrent pregnancy loss. Fertil Steril 2015; 104: 927-931. doi:10.1016/j.fertnstert.2015.06.044

[29] Cicinelli E, Matteo M, Tinelli R et al. Prevalence of chronic endometritis in repeated unexplained implantation failure and the IVF success rate after antibiotic therapy. Hum Reprod 2015; 30: 323-330. doi:10.1093/ humrep/deu292

[30] Craig LB, Ke RW, Kutteh WH. Increased prevalence of insulin resistance in women with a history of recurrent pregnancy loss. Fertil Steril 2002; 78: 487-490. doi:10.1016/S0015-0282(02)03247-8

[31] Tian L, Shen H, Lu Q et al. Insulin resistance increases the risk of spontaneous abortion after assisted reproduction technology treatment. J Clin Endocrinol Metab 2007; 92: 1430-1433. doi:10.1210/jc.2006-1123

[32] Cocksedge KA, Saravelos SH, Wang Q et al. Does free androgen index predict subsequent pregnancy outcome in women with recurrent miscarriage? Hum Reprod 2008; 23: 797-802. doi:10.1093/humrep/ den022

[33] Anselmo J, Cao D, Karrison T et al. Fetal loss associated with excess thyroid hormone exposure. JAMA 2004; 292: 691-695. doi:10.1001/jama. 292.6.691

[34] Wang Y, Zhao H, Li Y et al. Relationship between recurrent miscarriage and insulin resistance. Gynecol Obstet Invest 2011; 72: 245-251. doi:10.1159/000325165

[35] Triggianese P, Perricone C, Perricone R et al. Prolactin and natural killer cells: evaluating the neuroendocrine-immune axis in women with primary infertility and recurrent spontaneous abortion. Am J Reprod Immunol 2015; 73: 56-65. doi:10.1111/aji.12335

[36] Li W, Ma N, Laird SM et al. The relationship between serum prolactin concentration and pregnancy outcome in women with unexplained recurrent miscarriage. J Obstet Gynaecol 2013; 33: 285-288. doi:10.3109/01443615.2012.759916

[37] Jordan J, Craig K, Clifton DK et al. Luteal phase defect: the sensitivity and specificity of diagnostic methods in common clinical use. Fertil Steril 1994; 62: 54-62. doi:10.1016/s0015-0282(16)56815-0

[38] Vanky E, Stridsklev S, Heimstad R et al. Metformin versus placebo from first trimester to delivery in polycystic ovary syndrome: a randomized, controlled multicenter study. J Clin Endocrinol Metab 2010; 95: E448E455. doi:10.1210/jc.2010-0853

[39] Hahn KA, Hatch EE, Rothman KJ et al. Body size and risk of spontaneous abortion among danish pregnancy planners. Paediatr Perinat Epidemiol 2014; 28: 412-423. doi:10.1111/ppe.12142

[40] Abalovich M, Amino N, Barbour LA et al. Management of Thyroid Dysfunction during Pregnancy and Postpartum: An Endocrine Society Clinical Practice Guideline. J Clin Endocrinol Metab 2007; 92: s1-s7. doi:10.1210/jc.2007-0141

[41] Vissenberg R, Manders VD, Mastenbroek S et al. Pathophysiological aspects of thyroid hormone disorders/thyroid peroxidase autoantibodies and reproduction. Hum Reprod Update 2015; 21: 378-387. doi:10.1093/humupd/dmv004

[42] Bernardi LA, Cohen RN, Stephenson MD. Impact of subclinical hypothyroidism in women with recurrent early pregnancy loss. Fertil Steril 2013; 100: 1326-1331. doi:10.1016/j.fertnstert.2013.07.1975

[43] [Anonym]. Erhöhter TSH-Wert in der Hausarztpraxis. S2k-Leitlinie. AWMF-Register-Nr. 053-046 DEGAM-Leitlinie Nr. 18 ed. Accessed October 19, 2020 at: https://www.awmf.org/leitlinien/detail/I/053-046.html

[44] Shah D, Nagarajan N. Luteal insufficiency in first trimester. Indian J Endocrinol Metab 2013; 17: 44-49. doi:10.4103/2230-8210.107834

[45] Ogasawara M, Kajiura S, Katano K et al. Are serum progesterone levels predictive of recurrent miscarriage in future pregnancies? Fertil Steril 1997; 68: 806-809. doi:10.1016/s0015-0282(97)00328-2 
[46] Saccone G, Schoen C, Franasiak JM et al. Supplementation with progestogens in the first trimester of pregnancy to prevent miscarriage in women with unexplained recurrent miscarriage: a systematic review and meta-analysis of randomized, controlled trials. Fertil Steril 2017; 107: 430-438.e433. doi:10.1016/j.fertnstert.2016.10.031

[47] Roberts LN, Patel RK, Arya R. Venous thromboembolism and ethnicity. $\mathrm{Br} J$ Haematol 2009; 146: 369-383. doi:10.1111/j.13652141.2009.07786.x

[48] Rodger MA, Betancourt MT, Clark P et al. The association of factor V leiden and prothrombin gene mutation and placenta-mediated pregnancy complications: a systematic review and meta-analysis of prospective cohort studies. PLoS Med 2010; 7: e1000292. doi:10.1371/journal.pmed. 1000292

[49] Arachchillage DRJ, Makris M. Inherited Thrombophilia and Pregnancy Complications: Should We Test? Semin Thromb Hemost 2019; 45: 50 60. doi:10.1055/s-0038-1657782

[50] Bohlmann MK. Effects and effectiveness of heparin in assisted reproduction. J Reprod Immunol 2011; 90: 82-90. doi:10.1016/j.jri.2011.03.004

[51] Clark P, Walker ID, Langhorne P et al. SPIN (Scottish Pregnancy Intervention) study: a multicenter, randomized controlled trial of low-molecularweight heparin and low-dose aspirin in women with recurrent miscarriage. Blood 2010; 115: 4162-4167. doi:10.1182/blood-2010-01267252

[52] Kaandorp SP, Goddijn M, van der Post JA et al. Aspirin plus heparin or aspirin alone in women with recurrent miscarriage. N Engl J Med 2010; 362: 1586-1596. doi:10.1056/NEJMoa1000641

[53] Schleussner E, Kamin G, Seliger G et al. Low-molecular-weight heparin for women with unexplained recurrent pregnancy loss: a multicenter trial with a minimization randomization scheme. Ann Intern Med 2015; 162: 601-609. doi:10.7326/M14-2062

[54] Tan WK, Lim SK, Tan LK et al. Does low-molecular-weight heparin improve live birth rates in pregnant women with thrombophilic disorders? A systematic review. Singapore Med J 2012; 53: 659-663

[55] Visser J, Ulander VM, Helmerhorst FM et al. Thromboprophylaxis for recurrent miscarriage in women with or without thrombophilia. HABENOX: a randomised multicentre trial. Thromb Haemost 2011; 105: 295-301. doi:10.1160/TH10-05-0334

[56] Rogenhofer N, Bohlmann MK, Beuter-Winkler P et al. Prevention, management and extent of adverse pregnancy outcomes in women with hereditary antithrombin deficiency. Ann Hematol 2014; 93: 385-392. doi:10.1007/s00277-013-1892-0

[57] Branch DW, Gibson M, Silver RM. Clinical practice. Recurrent miscarriage. N Engl J Med 2010; 363: 1740-1747. doi:10.1056/NEJMcP 1005330

[58] Derksen RH, Khamashta MA, Branch DW. Management of the obstetric antiphospholipid syndrome. Arthritis Rheum 2004; 50: 1028-1039. doi:10.1002/art.20105

[59] Miyakis S, Lockshin MD, Atsumi T et al. International consensus statement on an update of the classification criteria for definite antiphospholipid syndrome (APS). J Thromb Haemost 2006; 4: 295-306. doi:10.1111/j.1538-7836.2006.01753.x

[60] Perricone C, de Carolis C, Perricone R. Pregnancy and autoimmunity: a common problem. Best Pract Res Clin Rheumatol 2012; 26: 47-60. doi:10.1016/j.berh.2012.01.014

[61] Carp HJ, Shoenfeld Y. Recurrent spontaneous abortions in antiphospholipid syndrome: natural killer cells - an additional mechanism in a multi factorial process. Rheumatology (Oxford) 2007; 46: 1517-1519. doi:10.1093/rheumatology/kem219
[62] Tursi A, Giorgetti G, Brandimarte G et al. Effect of gluten-free diet on pregnancy outcome in celiac disease patients with recurrent miscarriages. Dig Dis Sci 2008; 53: 2925-2928. doi:10.1007/s10620-0080242-x

[63] Tersigni C, Castellani R, de Waure C et al. Celiac disease and reproductive disorders: meta-analysis of epidemiologic associations and potential pathogenic mechanisms. Hum Reprod Update 2014; 20: 582-593. doi:10.1093/humupd/dmu007

[64] Hadziselimovic F, Geneto R, Buser M. Celiac disease, pregnancy, small for gestational age: role of extravillous trophoblast. Fetal Pediatr Pathol 2007; 26: 125-134. doi:10.1080/15513810701563637

[65] Christiansen OB. A fresh look at the causes and treatments of recurrent miscarriage, especially its immunological aspects. Hum Reprod Update 1996; 2: 271-293. doi:10.1093/humupd/2.4.271

[66] Claus R, Hickstein H, Külz T et al. Identification and management of fetuses at risk for, or affected by, congenital heart block associated with autoantibodies to SSA (Ro), SSB (La), or an HsEg5-like autoantigen. Rheumatol Int 2006; 26: 886-895. doi:10.1007/s00296-005-0101-4

[67] Tincani A, Rebaioli CB, Taglietti M et al. Heart involvement in systemic lupus erythematosus, anti-phospholipid syndrome and neonatal lupus. Rheumatology (Oxford) 2006; 45 (Suppl.4): iv8-iv13. doi:10.1093/ rheumatology/kel308

[68] Toth B, Vomstein K, Togawa R et al. The impact of previous live births on peripheral and uterine natural killer cells in patients with recurrent miscarriage. Reprod Biol Endocrinol 2019; 17: 72. doi:10.1186/s12958-0190514-7

[69] Kuon RJ, Vomstein K, Weber M et al. The "killer cell story" in recurrent miscarriage: Association between activated peripheral lymphocytes and uterine natural killer cells. J Reprod Immunol 2017; 119: 9-14. doi:10.1016/j.jri.2016.11.002

[70] Hamulyák EN, Scheres L], Marijnen MC et al. Aspirin or heparin or both for improving pregnancy outcomes in women with persistent antiphospholipid antibodies and recurrent pregnancy loss. Cochrane Database Syst Rev 2020; (5): CD012852. doi:10.1002/14651858.CD012852.pub2

[71] van Dijk MM, Kolte AM, Limpens J et al. Recurrent pregnancy loss: diagnostic workup after two or three pregnancy losses? A systematic review of the literature and meta-analysis. Hum Reprod Update 2020; 26: 356 367. doi:10.1093/humupd/dmz048

[72] Kolte AM, Westergaard D, Lidegaard O et al. Chance of live birth: a nationwide, registry-based cohort study. Hum Reprod 2021. doi:10.1093/ humrep/deaa326

[73] Bernardi LA, Plunkett BA, Stephenson MD. Is chromosome testing of the second miscarriage cost saving? A decision analysis of selective versus universal recurrent pregnancy loss evaluation. Fertil Steril 2012; 98 : 156-161. doi:10.1016/j.fertnstert.2012.03.038

[74] Cicinelli E, Matteo M, Tinelli R et al. Chronic endometritis due to common bacteria is prevalent in women with recurrent miscarriage as confirmed by improved pregnancy outcome after antibiotic treatment. Reprod Sci 2014; 21: 640-647

[75] Kitaya K. Prevalence of chronic endometritis in recurrent miscarriages. Fertil Steril 2011; 95: 1156-1158

[76] Kitaya K, Matsubayashi H, Yamaguchi K et al. Chronic Endometritis: Potential Cause of Infertility and Obstetric and Neonatal Complications. Am J Reprod Immunol 2016; 75: 13-22 